\title{
Nobody kills himself if he doesn't want to kill the other
}

\author{
Reshetnikov M. M. \\ Based on plenary presentation the author made at the \\ psychological summit Golden Psyche 2019 (St. Petersburg, Russia, 2 June 2019). \\ ABSTRACT \\ In this paper, traditional and novel forms of suicidal behavior are analyzed from the \\ perspective of the death drive. Special attention is paid to such phenomena as "death \\ groups" and "suicide terrorism". Previously, suicide was described as a singular act \\ voluntarily and independently committed by an individual, but in the recent \\ decades, hundreds of episodes have occurred in which suicidal individuals killed \\ dozens or even hundreds of innocent people together with themselves. Results of \\ psychoanalytic studies of suicidal behavior are analyzed. Such contemporary societal \\ problems as loss of meaning and perverted ideological attitudes are discussed as an \\ influential cause of increase in aggressive and suicidal behavior.
}

Keywords: suicide, death groups, suicide terrorism, motives of suicidal behavior, loss of meaning.

There are many ways to lose your life. The best one is to keep living.

\section{UPSETTING STATISTICS}

Let us start with a definition. Suicide (from Latin sui caedere, to kill oneself) is intentional selfmurder, which is committed in most cases voluntarily and independently. According to official data, every year about one million people in the modern world commit suicide (10). In reality, the number is at least twice higher, as many versions of voluntary death are not qualified as suicide.

It is particularly upsetting that, according to Russian sociologists, one in a dozen teenagers has a history of suicide in his or her anamnesis, with the number of completed suicides among boys three times higher than among girls. It means that there are at least two potentially suicidal individuals in each class at a secondary school or in each university group. Some statistical data is even more upsetting; it should be also admitted that statistical data of psychologists, sociologists and psychiatrists on this phenomenon differ significantly, and no one can claim that his data is more accurate $(3,4,11)$. At the same time, the phenomenology of suicidal behavior in the XXI century has undergone certain transformations and qualitative change.

\section{DEATH GROUPS}

In the 2010s, specialists noticed that there were hashtags of "death groups" propagating suicide and death in social networks. In November 2016, one of the most famous founders of such groups, Philipp Budeikin (the group called The Blue Whale), was arrested on charges of inciting suicide of teenagers. In his interview to a St. Petersburg newspaper, this fraud psychologist said, in response to a question whether he had pushed teenagers to death: "Yes. I did it. Don't worry, you'll understand it. Everyone will understand it. They were dying happy. I gave them something they had never had in their life: warmth, understanding, connection". This statement of the undoubtedly mentally disturbed young man adequately captures the deficiency of certain feelings as one of the leading motives for teenage suicide. First of all, it is 
attachment, which should have grown into mutual understanding and warmth of interpersonal relationships, but stayed undeveloped. These feelings could be developed only in a normally functioning family. But it is well known that modern family is in crisis.

Suicide clubs existed already in ancient Egypt, and in the XIX century they were rather popular in Germany, Austria and the USA; they united eccentric and mentally unstable people. In addition to this fashionable eccentricity, we should take into account the phenomenon of psychic infection. V. M. Bekhterev (2) illustrates it with an example of 15 patients, who hanged themselves on one day at an institution for disabled persons in France. The history of psychiatry provides a lot of evidence that maniacal individuals are able to preach their ideas persistently, sincerely and often effectively; we can remember the crusades of children as an example.

However, until the 1980s, meeting such a maniac personality was a rare and random event for children and teenagers, who are more suggestable than mature people; it was something that could happen on the street, mostly in "bad" neighborhoods. The Internet has not only brought these maniac personalities into each and every house, from poor huts to fashionable homesteads, but has also made them full-fledged members of our families, sometimes even more authoritative and influential than parents, who cannot spend enough time with their children and pay enough attention to them. As child psychology proved, the child loves not a game but the person who he plays with. But modern children, starting from kindergarten, play with gadgets instead of toy cars and dolls. As a result, the computer becomes the loved object that satisfies the child's need for communication, almost like a living being, which the child trusts unconditionally, feels attached to, and wants to secure its love, just as previous generations of children tried to show obedience to their parents to secure their love.

In mid-February 2017, Russian authorities started "cleaning up" hashtags of death groups on the Internet, removing posts and comments, blocking personal pages etc. However, statistics has shown that these restrictive measures did not lead to the expected results. The number of participants in the death groups even increased, and by the beginning of 2017, there were more than 41,000 of them. At the same time, most of these "projects" and "players" moved from the social network VKontakte to Instagram. It should be also mentioned that instigation to suicide on the Internet is a criminal act that is extremely difficult to evidence. Thus, in the case of the above mentioned Budeikin, only two out of 15 episodes were proved in the court.

Founders of such groups take into account psychology of introverted teenagers who feel lonely. Addressing these participants, they often say something like: "This group is for people who feel not understood by others, who have their own voice and want to be heard...". One more specific characteristic should be mentioned here. Previously, in pre-Internet epoch, instigation to suicide was mostly personal, directed against someone close to the perpetrator and motivated by some egoistic reasons (to get heritage, to remove a competitor in love affair, to improve one's social or financial status etc.). However, currently we deal with instigation to suicide that is committed against complete strangers, unknown boys and girls, and its only motive is satisfying one's pathological striving for power over psyche and live of others, which it is obtained in an anonymous way.

Given the insignificant variability of the indicators, the averaged data is informative: $25 \%$ of the causes of youth suicides are related to problems in personal life, 18\% to relationships with parents and other family members, $15 \%$ to problems with peers, $11 \%$ to failures and disappointments, and $9 \%$ to loneliness. Together, these five types of problems explain 78\% of teenage suicides $(3,4,10,11)$. A much broader list of problems is given by V.M. Bekhterev in 
his unique work On the causes of suicide and its prevention (1912), thorough study of which is recommendable to everyone who deals with this problem (2).

\section{PSYCHOANALYSIS OF SUICIDAL MOTIVES}

Suicidal cases are usually investigated by law enforcement officials, but only from the perspective of the victim's conscious motives obtained from interviews with his relatives, friends, acquaintances, his correspondence, etc. This is often done just "for the record", very superficially, and police interrogation materials or information from relatives are not very trustworthy sources of information.

In this section we will discuss studies of suicidal behavior conducted by Freud and his followers. Let me remind you that in the 1920s, the concept of "the death drive", which is now recognized as universal for all humans, was first coined by psychoanalysis (20). It is much more difficult to accept the idea that any human psyche is to some degree pervaded by suicidal tendencies, which could be also considered in the context of the death drive, the instinct of aggression and self-destruction $(1,12)$.

Surprisingly, the phenomenon of suicide often seems to be a tabooed topic even in psychoanalytical studies, in which it is only briefly mentioned, as if one tries to forget or repress it immediately after reading Freud's works, or let it drown in a stream of other information. I am not sure whether all my colleagues are well acquainted with the works and cases mentioned here, but I hope the main idea will be understood.

Case of Anna 0. is well known as a typical case of hysteria $(5,16)$ and the first application of psychoanalytic method. But few people remember its background. Anna 0. (Bertha Pappenheim) had not initially been a hysterical personality. She had suffered a few episodes of severe psychological traumata, though. When she was 8 years old, her elder sister Henrietta died of tuberculosis. At that time, the family was reduced to poverty. Bertha had to leave her school to help mother at home, which made her jealous of her younger brother, who continued to study at the gymnasium. In 1880, her father fell ill with pleurisy and needed to be taken care of; once during a sleepless night at his bedside, Anna had hallucinations and a panic attack. Later, in addition to these symptoms, she developed transient visual and speech impairments, inability to speak her mother tongue, facial paresis, right arm paresis, refusal to eat, mood swings, etc. Bertha's condition deteriorated sharply after her father's death (05.04.1881). She refused to eat for several days, broke windows in her house and tried to cut her veins with the pieces of glass. Medical doctors gave her recommendations that were typical for that time: fresh air, a change of scenery, chloral and other sedatives. It was only in the process of catharsis therapy with J. Breuer (who was a friend of the Pappenheim family), when her condition improved significantly.

Breuer concluded that the goal of the therapy was achieved on June 7,1882 , when Bertha reconstructed, with catharsis, her first episode of hallucinations at her severely ill father's bedside. "She has been in perfect health ever since," wrote Breuer in her medical file. But, as it often happens with hysterical individuals, one neurotic syndrome had been replaced by another, and in this case, it was imaginary pregnancy syndrome. Breuer was extremely upset with this development and afraid of rumors and insinuations, thus he abruptly broke any contact with the patient and went with his wife on a trip to Italy. Freud re-interpreted this case; he explained both her improvement and the new syndrome by Anna's feelings to her father that were transferred to her therapist. Thus, the psychoanalytic concept of "transference" (1895) was coined, and one of the unconscious motives of suicide, connected to child-parent relationship, was discovered. Later, Berta Pappenheim became a well-known 
public figure and publicist, one of the leaders of the women's rights movement. She lived a long life and died at the age of 77.

In 1901, in his work Psychopathology of the everyday life (19), Freud wrote that in 1898 one of his patients had committed suicide because of an incurable disease of his genitals. This case is only briefly mentioned in this work, and we do not have any information about the patient or his analysis. Nevertheless, this allows us to formulate another hypothesis, that is, the idea of connection between suicidal behavior and sexual or love relationships. Not only Freud's patients would agree with it, but also the founder of the psychoanalysis himself. In 1885, in a letter to his future wife, Freud wrote that if they separate, he would kill himself (15). Later Freud repeatedly returned to this topic and drew parallels between falling in love (as a version of insanity) and suicide.

In my work Psychic Trauma (6), I have already analyzed the psychodynamics of love crisis. Let me remind you these ideas. When a person loves someone, he partially invests his self into the beloved object (the object of his love), but mostly (due to natural narcissism) introjects the beloved object into his own self (the Ego), up to the metaphorical desire of absorption and appropriation of this object by his Ego. In cases of real love, the Ego is overflown by the object. Thus, there is an expansion and enrichment of one's Ego due to the incorporated object. The loss of such an endeared object, regardless of whether it has actually occurred or is only anticipated, provokes an intense conflict between the Super-Ego and the Ego, which is weakened because it is associated with the beloved object, incorporated and lost. The SuperEgo transforms into a cruel punishing psychic structure, which torments the Ego, accuses it of this loss and, depriving it of its defense, pushes it towards self-destructive behavior (hitting the table, or banging one's head against the wall, or inflicting wounds or injuries to itself, up to suicide).

In one of the most famous Freud's cases, the Wolf Man (14), Sergei Pankeyev's family predisposition to suicide, which some authors have interpreted as genetical, was omitted from the discussion. I think, however, that this case should be explained only by psychological (pathological) identifications and family background. It is well known that Sergei Pankeyev suffered from depression and other symptoms that were exacerbated by suicide of his beloved sister. When Pankeyev's father (who himself was prone to depressions) understood that his only son had suicidal ideation, he took Sergei to the greatest scientists of that time, V.M. Bekhterev and E. Krepelin, for consultation, but it was only Freud who his son started to trust. This case was re-analyzed by many authors, and I also devoted my paper The patient who was abused twice (7) to it. As we know, Pankeyev began his analysis with Freud in January 1910 and completed it in 1914; the analysis was successful, as Freud told the scientific community in one of his most famous works From the history of an infantile neurosis (1918). It should be mentioned that Pankeev was so impressed by Freud's personality that he immediately informed his father of his final decision to undergo therapy with him, which might have been one of the main factors of its success.

In the process of analysis, Pankeyev's childhood fears, including the fear of castration, were revealed. When he was three years old, his elder sister, probably out of curiosity, once started studying his penis or playing with it. In either case, it might be understood as seductive behavior, which was threatening to a sexually immature child. Later, Pankeyev tried to behave seductively with his nanny by playing with his penis in front of her; then he got a more real threat of castration. The nanny told him very strictly that if he behaved like that, he would get a wound "at this place". As Freud suggested, Sergei Pankeyev also had the trauma of the "primary scene", as a result of which he regressed to the anal stage of development, and his 
sadistic tendencies, which were manifested in early childhood, transformed into masochism, ideas of self-destruction and meaninglessness of life. After a few months of psychoanalysis, Pankeyev felt that a completely new world opened up to him, and many unclear things in his life started to clarify. In my analytic and supervisory practice, I had a lot of such cases, when patients came into analysis feeling desperate and absolutely hopeless. Sergei Pankeyev, who had suffered from depression and suicidal tendencies in his youth, lived a long life. Until 1950, he worked as an agent in a Viennese insurance company, then retired, and died at the age of 92 (7.05.1979), having survived the suicide of his beloved wife Teresa Keller (in 1938), a former nurse from a sanatorium in Munich, in which he was treated.

The next case was the case of Dora (1905), a young girl, frustrated by her father's affair with the wife of Mr. K., a man who she was secretly in love with; in retaliation for his wife's betrayal (and in the attempt to make a revenge upon Dora's father) the man tried to seduce Dora and kissed her persistently despite her resistance. Dora was overwhelmed by her affects and wrote a farewell letter to her parents (17). Let me remind you that she "accidentally" left the letter at the most vivid place in her the parents' hotel room. Of course, the parents saw the letter and asked Freud for help.

In my practice, I have repeatedly seen such cases, when suicidal thoughts were "unintentionally" disclosed to parents or spouses via friends or relatives. When motives of such actions or demonstrative suicide attempts (usually planned in such a way that they should lead to a happy end) were analyzed, most frequent explanation was: "I wanted to make them understand". The contents of what exactly the relatives or partners should understand varied from highly spiritual to the most primitive ones. In some cases, these were ideas, including religious ideas, which were not shared by the family, or one's problematic sexual orientation, while other examples included parents' refusal to buy their 14-year-old daughter a new fancy smartphone.

The most important thing in such cases is that the idea of suicide can be a kind of message, and in the process of therapy it is very important to establish not only the motive, but also the recipient of this message and its transformations in the process of transfer. Usually these recipients are the most loving and beloved people in one's circle, and sometimes the therapist himself becomes such a recipient. It should be mentioned that, although the WHO (2011) states in its definition that "suicide is the result of one's conscious actions", young people often do it spontaneously under the influence of feelings, affects and unconscious motives. Full awareness is typical almost exclusively for so-called "altruistic suicides" of terminally ill elderly people, who want to get rid of their suffering and spare their loved ones of it. Other cases of "altruistic suicides" were due to escape from shame by HIV-positive people during the period of thoughtless stigmatization of these patients.

In 1909, Freud published the Rat Man case (14), in which another motive for suicide is described, that of rivalry and ambivalence. A 29-year-old lawyer Ernst Lanser suffered from obsessive neurosis: obsessive thoughts and rituals had paralyzed his life energy to such a degree that he lost any ability to work. He developed these symptoms in the army, when he heard a story about a brutal Eastern torture: a pot with rats is tied to one's buttocks, so that the rats eat their way through the victim's anus. Lanser started imagining this picture projected onto his father and his beloved woman to whom he had ambivalent feelings. Later this case was interpreted as a version of anal eroticism. Freud's therapy was a success. The patient fully recovered and resumed his usual activities and contacts with other people, who he had avoided. In August 1914, Lanser was drafted into the army, captured and killed. 
At the beginning of the XX century, the motive of rivalry was shown to be playing an important role in suicides of Vienna university students; it was widely spread among students of creative professions, such as musicians and artists. This phenomenon was given a proper explanation. After a child's talents were highly appreciated by his parents and peers in a provincial town, and he was admitted to an art school or conservatory in the capital city, he would suddenly discover that there were many more talented young people around him; such competition might become unbearable. Let us repeat it: this is another motive for suicide, a way of overcoming narcissistic trauma and rivalry.

The next case to be mentioned is that of paranoid judge Schreber (1911), who repeatedly asked the attending physicians to give him cyanide or tried to drown himself (18). This work, entitled Psychoanalytic notes a paranoia case ...is unique in that Freud never met Dr. Daniel Paul Schreber in person, but analyzed Memoirs of a nervous patient, which Schreber published in 1903. This case is remarkable indeed. Schreber developed a mental disorder (hypochondrial depression) at the age of 42 , when he lost the Reichstag election. He spent several months at Professor Flechsig's clinic, recovered and was discharged. However, at the age of 53, after his appointment as the President of the Court of Appeal Collegium in a provincial place, he developed acute delusions and had to be hospitalized to the same clinic where he had spent 8 years. He left the clinic only after he spoke at the tribunal in Dresden court as his own defendant proving that he was not a threat to society. It was for this occasion that he wrote Memoirs... to prove that he could be released from the clinic. Schreber achieved his goal, but five years later he had psychotic relapse, was admitted to the same clinic and spent there four more years until his death (1911).

Schreber's paranoid "core" was the idea of his special mission on rescuing the world, for which goal he had to be transformed into a woman. In interpreting this case, Freud concluded that his mental disorder was caused, with the background of previously developed depression, by the "influx" of homosexual libido directed at Dr. Schreber's attending physician Professor Flechsig. Thus, we can identify another factor of suicidal behavior, intra-personal conflicts based on abnormalities in sexual identity. Freud returns to this idea in his work On the psychogenesis of a case of a female homosexuality (1920), where he describes a young girl's jealousy of her mother's relationship with her recently born sibling as the reason of her suicidal thoughts and an attempt to jump under the train (21). As a result of these feelings, the daughter distanced from her mother and fell in love with another woman, much older than herself.

Let us turn to one of Freud's most famous works Mourning and Melancholy (1917), in which the leading symptomatology was not depression (in rather simplified schematic description) but an overwhelming feeling of guilt and endless self-reproach.

Everyone is familiar with mood swings, when one can be asked "Are you upset about something?" These feelings usually have rational, analyzable and explainable connection with a particular situation or with a psychic trauma. In such times, one becomes less energetic, somewhat slow and self-absorbed, clings to a psycho-traumatic topic and shows lack of interest in all others; he is either isolated or, otherwise, tends to discuss the traumatizing topic with those close to him or even with complete strangers. Of course, both performance and selfesteem are affected, but such a person is still able to perform, to interact with others, to understand them and himself and to be aware of the reasons of his bad mood. Freud denotes it as a normal "mourning". Usually, such a person would not consult a psychotherapist or psychologist. After a while, he will forget about this disturbance and its reason. This behavior is not perceived as pathological, as it always has a clear reason and a specific explanation. 
In contrast to that, melancholy (Freud uses this term as an equivalent of severe depression) is a qualitatively different condition. Freud mentions that it is characterized by loss of interest in the outside world, pervasive lethargy, inability to act, lowering of self-esteem, which is expressed in endless self-reproach and self-depreciation. In some cases, this mounts to a delusional guilt with expectation of punishment for real or imaginary transgressions, which the patient himself considers unforgivable. But the most important difference from the usual mourning is that the patient himself, at the conscious level, does not know the cause of his suffering.

Freud calls it splendid impoverishment of the self and states that in case of mourning, the world is perceived as impoverished and empty, while in case of melancholy the Ego is perceived in such a way. The patient depicts himself as an exceptionally nasty, incapable, even disgusting person, and he might be surprised that the therapist still deals with such a worthless human being. This characteristic of melancholia is well known to professionals; the connection between suicide and depression is well-established, and all cases of severe depression can be considered pre-suicidal conditions $(8,11)$. This condition is often caused by some events in the patient's past (sometimes very early life), which were so abominable, disgusting, and "stinking", as Freud puts it, that it is equally impossible to remember and to forget them. It is extremely difficult to come in contact with such memories. Metaphorically speaking, one cannot remember what has not been forgotten. The main purpose of therapy in these cases is to revive, in a safe environment, these frightening, real, partially or even completely fantasy-transformed memories, and to disentangle them from their perceived unnaturalness and painful fear of guilty feelings, which often do not belong to the person who presents such symptoms.

I will illustrate it with an example described in detail in my book Private Visits. The patient, a woman about 30 years old, who came to St. Petersburg from a different city, with a university degree, was sent to me by her mother because of severe depression, inability to work and a number of suicide attempts. For a few dozen sessions, the patient promised to tell me about her main symptom, which she was not ready to discuss yet. In the end, she revealed that when she felt any kind of nervousness, especially sexual arousal, she would suffer from gas incontinence. It took many months of careful immersion into her early memories before she remembered that as a little girl, she was sexually abused by her mother, who would come into her bed and harass her after quarreling with father. Prior to the therapy, the patient had not remembered it, and even in therapy she did not understand it at once that her symptom was protective, and its purpose was to make her unpleasant as a sexual object. I can't call this case successful, because the patient inquired her mother about the events, and the latter immediately stopped paying for our sessions and took her daughter home.

Let's stop here and notice that, despite all the differences in clinical manifestations, almost all these patients had suicidal ideation. This leads us to the conclusion that there might be no mental disorders without predisposition to suicide, and vice versa. Due to Freud and his followers in the area of psychoanalysis, it has been universally recognized that suicidal ideation is actually a striving to kill someone else, someone who had betrayed the patient, or competed with him, or misunderstood him, someone who stirs his deepest love and at the same time hated $(1,12,23)$.

Such thoughts are "localized" is the unconscious part of the Ego and in the Super-Ego. It is useless to look for these thoughts in the Id, to which the idea of death is unknown. In order to live and be happy, the Ego must feel loved by the Super-Ego (this is one of the goals of therapy). Nevertheless, we must recognize that everyone has such situations, when hardships of life 
seem unbearable, and our tolerance towards them and ourselves is depleted; as a result, life becomes meaningless, dull and devalued. In such cases, of course, the Other is needed who is trained to let his Ego be used as a "crutch" for someone temporarily unable to walk.

\section{SUICIDAL TERRORISTS}

In conclusion, let us consider specifics of some contemporary suicides. Previously, suicide was universally defined as a single case which affects only the individual and his grieving relatives. But currently, hundreds of cases have been described, which are qualitatively different. The most striking of these was the recent tragedy of German Wing's flight A320-211 (24.03.2015), when Andreas Lubitz, a pilot who had a mental disorder, deliberately directed the plane into the mountain and thus made 144 passengers and 6 crew members accompany him in his suicide. This is a qualitatively different manifestation of human aggressiveness and its particular case, misanthropic suicidality, which has not been thoroughly explored yet. In his works and in correspondence with Albert Einstein, Sigmund Freud repeatedly drawn an analogy between suicide and war (13). We can ask ourselves, what will happen if a person, who feels suicidal like the pilot Lubitz and who has access to powerful technology as an operator of a nuclear power plant, a ballistic missile station or even an ordinary dam, wants to make several thousand or several million other people accompany him in his suicide?

These ideas are actively propagated in suicide bombers' manuals, which emphasize: "The more victims, the sooner they will understand it". Such cases might be interpreted as a message, but I think that would be wrong. In my opinion, more adequate explanation takes into account perverse striving for recognition, or at least posthumous fame, of a pathological personality with inflated self-esteem and lack of ability to achieve recognition in other ways. Indeed, who would read Breivik's 1500-page-long manifesto if this 32-year-old pathological narcissist had not shot 77 of his compatriots? But after his brutal and cynical crime, the book has been translated into all main languages. And who would have even noticed the suicide of a 28-yearold man, a second pilot, if he hadn't condemned 160 innocent people to death?

\section{ON THE LOSS OF MEANING}

Another explanation of such behavior was given in 2011 by James Fox, a professor at the North-Eastern Boston University (USA), who said: "In American society, there are people who are angry with the whole world, completely disillusioned, consider their lives ruined and do not want to live anymore. These people lack emotional support from their families and friends. And they decide to take cruel revenge on those who, as they think, are responsible for their failures, who deprive them of a possibility to cope with their problems. When choosing between suicide and bloodshed, they choose both" 1 . I think, this situation is typical not only for the USA.

As early as in the 1960s, V. Frankl wrote about widely spread loss of meaning of life (22). According to his statistics, it led to increase in the level of depression, drug addiction, alcoholism and aggressiveness, including auto-aggression. After a long discussion that took place in early 2000s, St. Petersburg scientists came to the conclusion that meanings of life are not discovered but rather introduced by outstanding thinkers such as Voltaire, Diderot, Rousseau, Locke, Hobbs or even Marx. In addition, it was argued that an individual acquires the meaning only if he has a good cause, even illusory one, that is far beyond his daily existence and unites him with other people. Do we, as humankind, or at least as citizens of a particular

1 The interview that Prof J. Fox gave to Rossijskaya Gazeta on 15.12 .2012 commenting the massacre at the primary school Sandy Hook (the USA), in which 28 people were shot dead, including 20 children age 5 to 10. 
country, have such ideas and goals? Were we all born just to enjoy our meals, to make fashionable hairstyles or tattoos, to earn money for new jeans, or a new smartphone, or a new apartment, or a car, or a country house? Are there any outstanding contemporary thinkers, whose ideas can unite us all?

\section{IDEOLOGICAL VACUUM}

The notion of ideology has become a tabooed topic. Some people believe that there is no more ideology at all. This is not the case, and we will return to this idea later. But first, let us discuss the role of ideology. Any ideology has two main functions: 1) it should give explanations aimed at smoothing out contradictions; 2) it should give meaning to everyday life that unites all citizens of the country. Soviet people had such an ideology, which was, of course, illusory and utterly discredited in the process of building the communism, but it still existed! Now there is no such ideology. As we know, it was cancelled at once in 1991. There was nothing to replace it but the transient illusion of joining the nicely smelling (under closer inspection, stinking) West! It was the most powerful national psychic trauma, a trauma of loss of meaning and faith. In 1992, the frequency of suicides in Russia peaked at 46.1 per 100,000 people; the number gradually decreased, and by 2012 it was 22.4 . There are many studies analyzing the connection between the suicide rate and environmental and economic factors, national traditions and specifics $(4,10,11)$, but it is not the case for socio-psychological factors and meaning of life, the notions which have long been excluded from programs of almost all parties.

At present, most sociologists and even politicians state that contradictions in society, financial stratification and spiritual disunion are growing. We need to admit that such processes are typical not only for Russia but for the whole world, and ideas of justice and fight against injustice are getting more and more widely spread (9). Actually, it is fight against a new ideology, which has not been explicitly declared as such, but is still active. To put it briefly, it is the ideology of unrestrained competition, the struggle of everyone against all, the sacralization of material success and commodity fetishism. Great humanist thinkers would be horrified by this outcome of private enterprise, free competition and democracy, which is increasingly turning into democratism.

\section{AN UNNOTICED EVENT}

In 1960s, there was another event that almost nobody noticed. Until the mid-twentieth century, the mankind was moving towards humanization of relationships between people and states in accordance with the ideas proclaimed by the abovementioned, as well as other, outstanding thinkers. None of these thinkers held any high positions, they were neither ministers nor kings, tsars or presidents; however, ministers, monarchs and presidents listened to their ideas, accepted them and implemented them in their policies. And suddenly, in the middle of the twentieth century, a qualitative shift happened: the right to proclaim new ideas passed from outstanding thinkers to the first persons of states, who are not obliged to be brilliant thinkers at all and are typically individuals with aggressive leadership personality. They reach their positions in result of uncompromised political competition and struggle, and they stick to the same behavior and style of relationships in their personal and international affairs. Where can such leaders lead us?

\section{References}

Adler A. Aggressive Drive in Life and Neurosis //The First Private Psychoanalytical Meeting in Salzburg, April 27, 1908 /Ed. Otto Rank / Transl. from German. - Izhevsk: ERGO, 2011. - pp. 27-28.

Adler A. Vlechenie k agressii v zhizni i v nevroze // V kn.: Otchet o pervom chastnom Psihoanaliticheskoj sobranii v Zal'cburge 27 aprelja 1908 goda (tekst). / Sost. i ref. Otto Rank / Per. s nem. - Izhevsk: ERGO, 2011. -S. 27-28.

Bekhterev, V.M. On the causes of suicide and its prevention // Popov Y.V., Pichikov A.A. Suicidal behavior of teenagers. - St. Petersburg, SpetsLit, 2017. - pp. 8-44. 
Behterev V.M. 0 prichinah samoubijstva i vozmozhnoj bor'be s nim. // V kn. Popov Ju.V., Pichikov A.A. Suicidal'noe povedenie u podrostkov. - Sankt-Peterburg, SpecLit, 2017. - S. 8-44.

Efremov V.S. Survivors: working with a suicidal person. - 2nd edition - St. Petersburg: Publishing Center "Humanitarian Academy", 2018. - 272 pp.

Efremov V.S. Ostavshiesja v zhivyh: rabota s suicidentom. - 2-e izd. - Sankt-Peterburg: Izdatel'skij centr «Gumanitarnaja akademija», 2018. - 272 s.

Popov Y.V., Pichikov A.A. Suicidal behavior of teenagers. - St. Petersburg, SpetsLit, 2017. - pp. 8-44.

Popov Ju.V., Pichikov A.A. Suicidal'noe povedenie u podrostkov. - Sankt-Peterburg, SpecLit, 2017. - S. 8-44.

Reshetnikov M.M. Historical and cultural prerequisites of psychoanalysis. // Psychoanalysis: textbook for bachelor and master programs. Ed. by M.M.Reshetnikov. - Moscow: Publishing House Urait, 2016. - pp. 17-29.

Reshetnikov M.M. Istoriko-kul'turnye predposylki sozdanija psihoanaliza. // V kn. Psihoanaliz: uchebnik dlja bakalavriata i magistratury. Pod red. M.M.Reshetnikova. - Moskva: Izdatel'stvo Jurajt, 2016. - S. 17-29.

Reshetnikov M.M. Psychic trauma: textbook for bachelor, specialist and master programs. - 2nd edition - Moscow: Publishing House Urait, 2018. -pp. 50-51.

Reshetnikov M.M. Psihicheskaja travma: uchebnoe posobie dlja bakalavriata, specialiteta i magistratury. - 2-e izd. - Moskva: Izdatel'stvo Jurajt, 2018. - S. 50-51.

Reshetnikov, M.M. The patient who was abused twice // Reshetnikov M.M. Difficulties and typical mistakes of the beginning of therapy. - 2nd edition - Moscow: Publishing House Urait, 2017. - pp. 225-240.

Reshetnikov M.M. Dva sluchaja zloupotreblenija odnim pacientom. // V kn. Reshetnikov M.M. Trudnosti i tipichnye oshibki nachala terapii. - 2-e izd. - Moskva: Izdatel'stvo Jurajt, 2017. -S. 225-240.

Reshetnikov M.M. Psychodynamics and Psychotherapy of Depressions. - St. Petersburg, East European Psychoanalytic Institute, 2003. -328 pp.

Reshetnikov M.M. Psihodinamika i psihoterapija depressij. - Sankt-Peterburg, Vostochno-Evropejskij Institut Psihoanaliza, 2003. -328s.

Reshetnikov M.M. Intolerance and terrorism in Europe // The idea of non-violence in the XXI century. // Collection of scientific works. - Perm: PSU, 2006. - pp. 226-273.

Reshetnikov M.M. Intolerantnost' i terrorizm v Evrope // Ideja nenasilija v XXI veke. // Sbornik nauchnyh dokladov. - Perm': PGU, 2006. - S. 226-273.

Suicides in Russia and Europe / Ed. by B.S. Polozhij. - Moscow: Publishing House Medical Information Agency, 2016. - 212 pp.

Suicidy v Rossii i v Evrope / Pod red. B.S. Polozhego. - Moskva: 000 Izdatel'stvo «Medicinskoe informacionnoe agenstvov», 2016. $-212 \mathrm{~s}$.

Suicidology: the past and the present: the problem of suicide in works of philosophers, sociologists, psychotherapists, and in literature/ $2^{\text {nd }}$ Ed. - Moscow: Kogito-Center, 2013. - 569 pp.

Suicidologija: proshloe i nastojashhee: Problema samoubijstv v trudah filosofov, sociologov, psihoterapevtov i v hudozhestvennyh tekstah / Izd. 2-e, stereotipnoe. - Moskva: Kogito-Centr, 2013. - 569 s.

Freud S. Vicissitudes of drives. // S. Freud. Collected works, 10 volumes. V. 3. Psychology of the unconscious. Ed. by A.M. Bokovikov and S.I. Dubinskaya. - M.: LLC "Firma STD", 2006. - pp. 79-111.

Frejd Z. Vlechenija i ih sud'ba. // Z.Frejd. Sobr. soch. v 10 tomah. T. 3. Psihologija bessoznatel'nogo. Pod red. A.M. Bokovikova i S.I. Dubinskoj. - M.: 000 «Firma STD», 2006. - S. 79-111.

Freud S. Why war. Correspondence with Albert Einstein, September 1932. / Freud S. Beyond the pleasure principle. - Moscow, 1992. - pp. 325-337.

Frejd Z. Pochemu vojna. Perepiska s Al'bertom Jejnshtejnom, sentjabr' 1932. / V kn. Frejd Z. Po tu storonu principa udovol'stvija. - Moskva, 1992. - S. 325-337.

Freud S. Collected works, 26 volumes. V. 4. Obsessive disorders. Rat Man. Wolf man. / Transl. from German by S. Pankov. - St. Petersburg: East European Psychoanalytic Institute, 2007. - 320 pp.

Frejd Z. Sobr. soch. v 26 tomah. T. 4. Navjazchivye sostojanija. Chelovek-krasa. Chelovek volk. / Per. s nem. S. Pankova. - Sankt-Peterburg: Vostochno-Evropejskij Institut Psihoanaliza, 2007. - 320 s.

Freud S. Letters to the bride. / Transl. from German by S. Laine. - Moscow: ABC (Classic), 2011. - 208 pp. 
Frejd Z. Pis'ma k neveste. / Per. s nem. S. Lajne. - Moskva: Azbuka (Klassika), 2011. - 208 s.

Freud S. Fräulein Anna 0. // S. Freud. Collected works, 26 volumes. V. 1. Studies of hysteria. / Transl. from German by S. Pankov. - St. Petersburg: East European Psychoanalytic Institute, 2005. - pp. 39-70.

16. Frejd Z. Frejlejn Anna 0. // Z. Frejd. Sobr. soch. v 26 tomah. T. 1. Issledovanija isterii. / Per. s nem. S. Pankova. Sankt-Peterburg: Vostochno-Evropejskij Institut Psihoanaliza, 2005. - S. 39-70.

Freud S. Fragment of analysis of a hysteria case. // S. Freud. Collected works, 26 volumes. V. 5. Phobic disorders. Little Hans. Dora. / Transl. from German by S. Pankov. - St. Petersburg: East European Psychoanalytic Institute, 2012. - pp. 143-268.

Frejd Z. Fragment analiza odnogo sluchaja isterii. // Z. Frejd. Sobr. soch. v 26 tomah. T. 5. Fobicheskie rasstrojstva. Malen'kij Gans. Dora. / Per. s nem. S. Pankova. - Sankt-Peterburg: Vostochno-Evropejskij Institut Psihoanaliza, 2012. - S. 143-268.

Freud S. Psychoanalytical notes on an autobiography describing a case of paranoia (dementia paranoides) // S. Freud. Collected works, 26 volumes. V. 3. Possession by the devil. Paranoia. / Transl. from German by S. Pankov. St. Petersburg: East European Psychoanalytic Institute, 2006. - pp. 71-146.

Frejd Z. Psihoanaliticheskie zametki ob odnom sluchae paranoji (dementia paranoides), opisannom v avtobiografii. // Z. Frejd. Sobr. soch. v 26 tomah. T. 3. Oderzhimost' d'javolom. Paranojja. / Per. s nem. S. Pankova. - Sankt-Peterburg: Vostochno-Evropejskij Institut Psihoanaliza, 2006. - S. 71-146.

Freud S. Collected works, 26 volumes. V. 8. Psychopathology of the everyday life. / Transl. from German by A. Bokovikov. - St. Petersburg: East European Psychoanalytic Institute, 2018. - 368 pp.

Frejd Z. Sobr. soch. v 26 tomah. T. 8. Psihopatologija obydennoj zhizni. / Per. s nem. A. Bokovikova. - SanktPeterburg: Vostochno-Evropejskij Institut Psihoanaliza, 2018. - 368 s.

Freud S. The Ego and the Id // S. Collected works, 10 volumes. V. 3. Psychology of the unconscious. Ed. by A.M. Bokovikov and S.I. Dubinskaya. - Moscow: LLC "Firma STD", 2006. - pp. 291-352.

Frejd Z. Ja i Ono. // Z. Frejd. Sobr. soch. v 10 tomah. T. 3. Psihologija bessoznatel'nogo. Pod red. A.M. Bokovikova i S.I. Dubinskoj. - Moskva: 000 «Firma STD», 2006. - S. 291-352.

Freud S. On psychogenesis of a case of female homosexuality. // S. Freud. Collected works, 26 volumes. V. 10. Dynamics of transference. V. 11. Psychoanalytic clinical theory. / Transl. from German by A. Bokovikov. - St. Petersburg: East European Psychoanalytic Institute, 2019. - pp. 349-378.

Frejd Z. O psihogeneze odnogo sluchaja zhenskoj gomoseksual'nosti. // Z. Frejd. Sobr. soch. v 26 tomah. T. 10. Dinamika perenosa. T. 11. Psihoanaliticheskaja klinicheskaja teorija. / Per. s nem. A. Bokovikova. - SanktPeterburg: Vostochno-Evropejskij Institut Psihoanaliza, 2019. - S. 349-378.

Frankl V. Suffering from meaningless of life. - Siberian University Publishing House, 2019. - 95 pp.

Frankl V. Stradanija ot bessmyslennosti zhizni. - Sibirskoe universitetskoe izdatel'stvo, 2019. - 95 s.

Stekel B. On the hysteria of fear. // The first private Psychoanalytical Meeting in Salzburg on April 27, 1908 / Ed. by Otto Rank / Transl. from German. - Izhevsk: ERGO, 2011. - pp. 23.

Shtekel' V. Ob isterii straha. // V kn.: Otchet o pervom chastnom Psihoanaliticheskoj sobranii v Zal'cburge 27 aprelja 1908 goda (tekst). / Sost. i ref. Otto Rank / Per. s nem. - Izhevsk: ERGO, 2011. - S. 23. 